\title{
Investment Nature of Real Properties on the Example of Wielka Wieś Municipality**
}

\section{Investment Nature of Real Properties}

Real properties, on account of their high capital intensity, are interesting subjects of various studies and analyses, which focus first of all on their usability, represented by value. It is created by number of factors, which to great extend can be identified and described. The number of them is strictly related to type of real property and the way in which it is used. The notion of real property's attribute appears in respect to real property appraisal, especially in terms of specifying market value of the property. One of the main stages here is the market analysis, the aim of which is to determine the real property characteristics which affect the level of transaction prices, but also to define the ranks of these characteristics, indicated by the so-called "weights" of the attributes.

The market value, apart from its definition given in the Real Property Management Act of 21 August 1997 [10], has detailed characteristics included in Appraisal Standards [6], which oblige the real property appraiser to determine the way of the most profitable use of a given real property, which depends on the appraisal purpose, provisions of law, status and intended use of the property as well as the market position. The most profitable way of real property use is understood as the use of real property which is physically possible, properly justified, legally accepted, economically cost-effective and ensuring its highest value. The choice of optimum way of use, especially if it is not the same as the existing one, requires conducting very careful market analysis, and especially looking at the real property in the perspective of its better use. It often leads to the situation when, during the appraisal of a given type of a real property, it is necessary to modify the attributes assumed, in

* AGH University of Science and Technology, Faculty of Mining Surveying and Environmental Engineering, Krakow, Poland

** The study has been carried out within the framework of Geomatics Department Statutory Research, Faculty of Mining Surveying and Environmental Engineering, AGH University of Science and Technology in Krakow, 2013 
order to make them correspond to the nature of the real property, taking into account its most profitable way of use, and not the existing one. The aspects discussed relate to the problem of real property being a subject of investment and employment of capital.

The investment can be defined [7] as long-term, risk-laden location of economic resources (investment inputs) in order to achieve profits in the future. It consists of the following elements:

- input (allocation of own and outside capital),

- profit, meaning the expected effect of the investment realisation,

- time - the period between the capital engagement and the achievement of profits,

- risk, as a possible deviation of the planned input value, profits from the period of capital engagement.

In references [1, 7] investments can be divided into two basic types:

1) financial - cash and capital market instruments, consisting in cash flows,

2) physical - components of physical assets, meaning fixed non-financial assets, intangible assets in relation to property rights, based on the flow of tangible assets.

Both investment groups [1] encompass real properties, where in case of financial investments these are for example shares in the companies and funds investing in the real property market or bonds of security. Material investments can be divided into locational, consisting to a great extent in speculative purchases of mainly undeveloped real properties in attractive locations, and productive, encompassing real properties related to production growth or efficiency increase.

The specific features of real property [5], as a subject of investment, are its durability, especially in relation to land; diversity, resulting from individual and unique features of each real property; scarceness, related to increasing land demand and their limited supply; and location, regarded as the most important attribute of a real property, decisive for its value, considered in physical and economic approach.

Investments in real property market the most often relate to the lands located in town/city areas or in their proximity, characterised by attractive location in terms of foreseen changes of real property prices, which enable achievement of satisfying effective rates that usually exceed inflation.

The ones particularly worth attention are agricultural real properties, being the main object of investments, characterised by incomparably lower prices than the lands intended for development. The market value of such properties should be first and foremost determined by the factors influencing their production capacity, such as various arable land types, the presence of soils of different agricultural applicability, the risk of soil erosion, soil culture, stoniness and the difficulty of soil cultivation as well as other features conditioned for example by location in flat or mountainous area [8]. It can be noticed, however, that in many cases relating 
to determining the market value of real properties located on farmlands, there is no significant correlation between these attributes and the achieved transaction prices, which also applies to offer prices. Such situation most often applies to the lands located in the villages and towns located in the vicinity of major urban centres, being highly popular among the buyers of building lands. It can be noticed that more decisive factors with regards to their values are such elements as distance from building areas, technical infrastructure or the quality of access roads. Therefore, this raises the problem of comparing real properties in terms of characteristic features typical for lands with agricultural use. Significant discrepancies are also noticeable in the level of prices of these real properties, depending mainly on the prospect of future transformation into building plots. A significant share of transactions involves speculative measures on the side of the buyers, who count on the increase in land value resulting from a change in their intended use. It's motivated by very high effective rates, low level of input required for the purchase of agricultural properties when compared to the lands intended for building as well as their high liquidity. Existing legislation, however, intended to protect agricultural lands, to a great extent depletes the supply of these real properties that could be considered in the category of a good financial investment.

One of the legal acts concerning the decultivation of land is the Farm and Woodland Conservation Act of 3 February 1995 [9], in which the protection of those lands is defined, inter alia, as the reduction in allocation of such lands for non-agricultural and non-forest purposes. As a basic group of lands that may be subject to actions aimed at using them for non-agricultural and non-forest purposes are wastelands, followed by the land of the lowest agricultural usability.

The investment process [4], the aim of which is to change the intended use of agricultural lands to other purposes, requires:

- obtaining approval for the change of agricultural land use for other purposes in respect of forest lands and arable lands of I-III classes;

- planning activities in form of appropriate arrangements in local area development plan (required in case of the lands mentioned above) or decision on land development and management conditions, which are the documents required when applying for a building permit;

- farmland conversion (except for arable lands made of mineral origin soils belonging to classes IV, IVA, IVB, V and VI), permitting other use than agricultural one.

The components of investing into agricultural properties include not only the profit but also risk, which is defined [1] as the probability of suffering loss, related to taking particular economic decision. It is the measure of results uncertainty, expected in the future as a result of a specific investment. Among the main risks we can mention systematic risk, resulting from external factors, which have the same impact on all similar investments, as well as unsystematic risk, related to investing in a particular type of assets. 
In case of capital investment in agricultural properties, treated as investment properties, a period of capital repayment is long and can last several years; there is also risk related to adverse legal changes, impossibility of farmland conversion and a drop in value of the property, although the latter does not seem justified.

Statistical data [2] of 2011 show that the lion's share, amounting to $77 \%$, of the total number of land property transactions, were arable lands and this way they comprised $66 \%$ of turnover value. In comparison to 2010, the turnover of this type of lands has increased by more than $7 \%$ in relation to the number of transactions and by almost $46 \%$ in terms of value.

The average transaction price per 1 ha, including both areas located within the administrative boundaries of cities and towns and in the countryside, amounted to about 46,000 PLN. The highest transaction prices for arable lands were recorded in Malopolskie, Mazowieckie and Silesia provinces.

\section{Undeveloped Land Property Market of Wielka Wieś Municipality}

The analysis was carried out in relation to undeveloped land properties located in the suburban Wielka Wieś municipality, in the Krakow poviat.

This municipality [11] is located around $15 \mathrm{~km}$ to the north from Krakow city centre, bordering with Krakow municipality from the south. It was previously a municipality of typically agricultural nature, which over the period of a dozen years or so has changed into suburban one. On account of significant interest in purchasing residential lands in this area, the supply of agricultural real properties, which now is $3,616 \mathrm{ha}$, is decreasing.

For the purpose of market analysis, a database was compiled with around 1,200 undeveloped land properties, which in the period 2003-2013 were the object of market trading. Majority of real properties (excluding the current year) were sold in $2007-24 \%$ of total number of transactions; the lowest level of contracts concluded was noted in 2003 - only $4 \%$. Share of the number of transactions in each year is presented in graphical form (Fig. 1).

The scope of the analysis relates to agricultural properties and the ones intended for single-family housing. Having eliminated from the set of transactions:

- purchases of real property with not uniform intended use,

- lands with functions other than residential and agricultural ones, made in tender procedure,

- with special conditions, such as the agreement between relatives or purchase of land to improve the utilisation of the buyer's plot of land, the database of 433 land properties was received, 329 positions of which are residential lands and 104 relate to farmlands. 


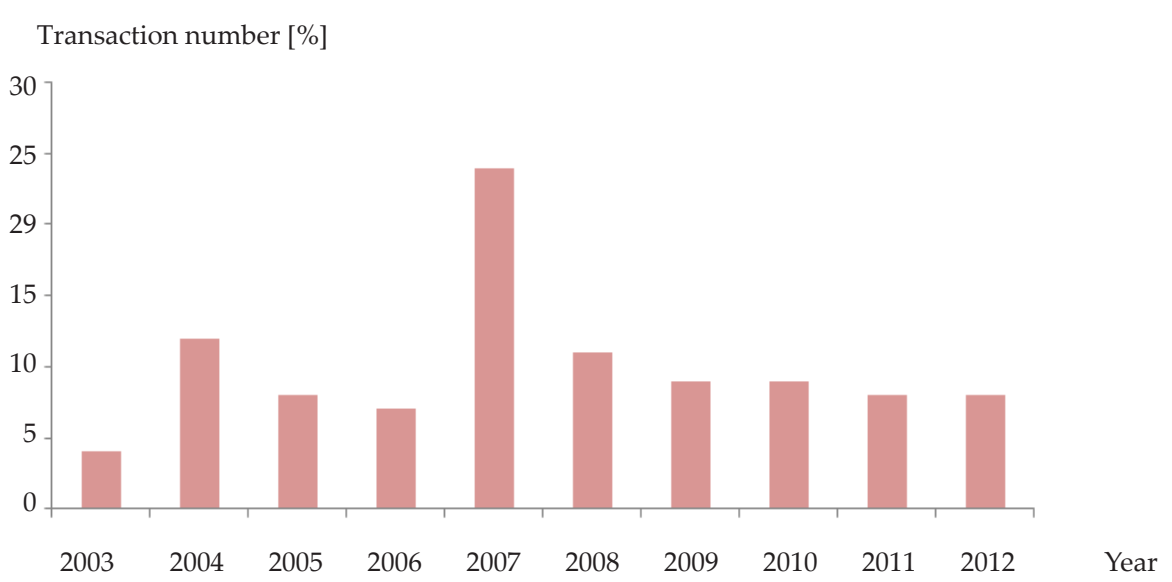

Fig. 1. Percentage share of transaction number in years 2003-2012

\section{Farmlands}

Information obtained on agricultural real properties sold indicates a significant decrease in the number of concluded purchase contracts. This results mainly from the limited supply of agricultural lands which are attractive in terms investment, and a very small number of sales offers for properties of this kind. The collected data come from the period 2003 to 2012. In these years, the increase in transaction prices obtained during agricultural lands sales can be observed, but every year there are transactions which greatly vary in terms of pricing (Fig. 2). Average price of agricultural lands in Małopolska province amounted to about 22,692 PLN/ha in the first quarter of 2013, and in 2004 it was at the level of about 7,874 PLN/ha.

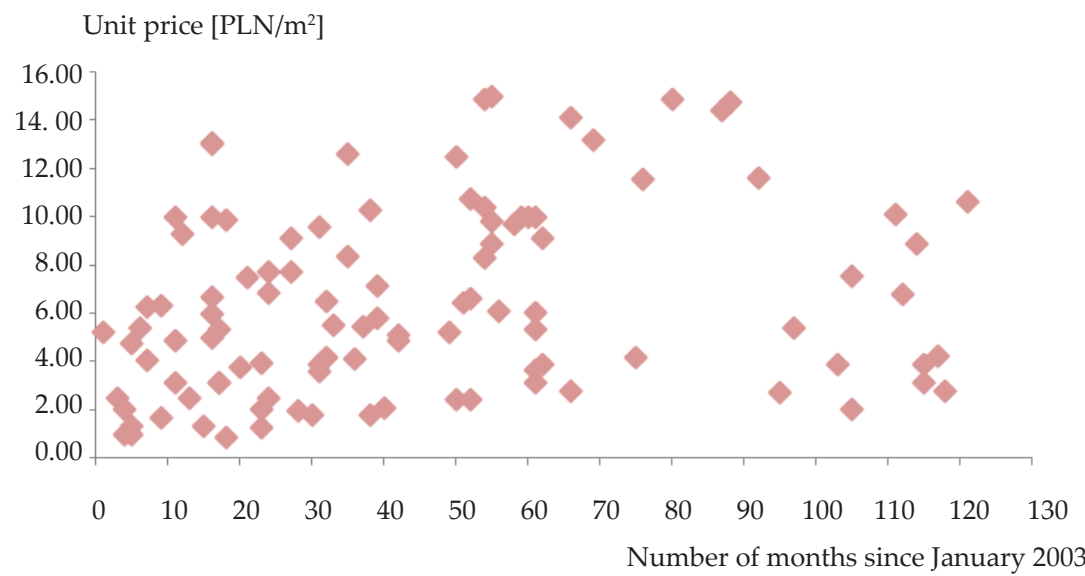

Fig. 2. Dispersion diagram of individual transaction prices in Wielka Wieś municipality in years 2003-2012 - farmlands 
The lowest average unit price for agricultural lands referred to the year 2003 and amounted to $4.29 \mathrm{PLN} / \mathrm{m}^{2}$ (determined on the basis of the database of 16 real properties) and the highest was reached in 2010 at the level of 10.87 PLN/m² (calculated on the basis of four transactions). In majority of the analysed annual periods, prices greatly vary, oscillating between about $1 \mathrm{PLN} / \mathrm{m}^{2}$ to about $10 \mathrm{PLN} / \mathrm{m}^{2}$. In the whole set of real properties the average price increase was $0.04 \mathrm{PLN} / \mathrm{m}^{2}$. On the basis of data collected, the average unit prices achieved each year were calculated (Tab. 1) as well as minimum and maximum unit prices and the number of transactions, on the basis of which these parameters were determined.

Table 1. The basic parameters describing the level of prices achieved in sales of undeveloped agricultural lands in years 2003-2012

\begin{tabular}{||c|c|c|c|c|c|c|c|c|c|c|}
\hline \hline \multirow{2}{*}{ Parameter } & \multicolumn{10}{|c|}{ Year } \\
\cline { 2 - 12 } & 2003 & 2004 & 2005 & 2006 & 2007 & 2008 & 2009 & 2010 & 2011 & 2012 \\
\hline \hline $\begin{array}{c}\text { Average unit } \\
\left.\text { price [PLN/m }{ }^{2}\right]\end{array}$ & 4.29 & 5.49 & 6.06 & 5.31 & 8.78 & 7.11 & 10.20 & 10.87 & 4.68 & 6.30 \\
\hline $\begin{array}{c}\text { Minimum unit } \\
\text { price [PLN/m²] }\end{array}$ & 0.97 & 0.87 & 1.76 & 1.75 & 2.40 & 2.78 & 4.17 & 2.74 & 2.02 & 2.77 \\
\hline $\begin{array}{c}\text { Maximum unit } \\
\text { price [PLN/m²] }\end{array}$ & 9.96 & 13.04 & 12.61 & 10.26 & 15.00 & 14.12 & 14.85 & 14.72 & 7.52 & 10.60 \\
\hline $\begin{array}{c}\text { Number of } \\
\text { transactions }\end{array}$ & 16 & 21 & 13 & 8 & 17 & 10 & 3 & 4 & 4 & 8 \\
\hline
\end{tabular}

Number of agricultural real property transactions over the years 2003-2012 has decreased sharply, while the number of contracts reported for the sale of undeveloped lands did not follow similar trend. A significant increase of interest in lands intended for residential development was observed in recent years, with concurrently decreasing number of transactions in relation to farmlands. It results mainly from the limited availability of properties of this type which would be offered for sale and at the same time would have features that attract potential investors.

Prices of agricultural lands have continued to grow, but investing in such type of properties usually entails purchasing of lands for which there is a chance of changing the status from agricultural to residential and conversion into buildable lands. Investments are considered in terms of achieving financial benefits from the sale of lands in the future, which will enable to generate high profits.

\section{Areas Intended For Single-Family Residential Development}

The collected database, after the initial selection, includes information on 329 properties. Prices vary and depend mainly on a city/town, where the property is located, its position in relation to the main communication routes and the 
neighbourhood. The diagram showing the dispersion of individual transaction prices during the analysed period of time (Fig. 3) shows a linear relationship between these variables and the high growth rate of these prices up to $1.27 \mathrm{PLN} / \mathrm{m}^{2}$ monthly. Unit prices are correlated with the date of the transaction at the level of 0.64 , where the square of correlation coefficient amounts to 0.42 .

Unit price $\left[\mathrm{PLN} / \mathrm{m}^{2}\right]$

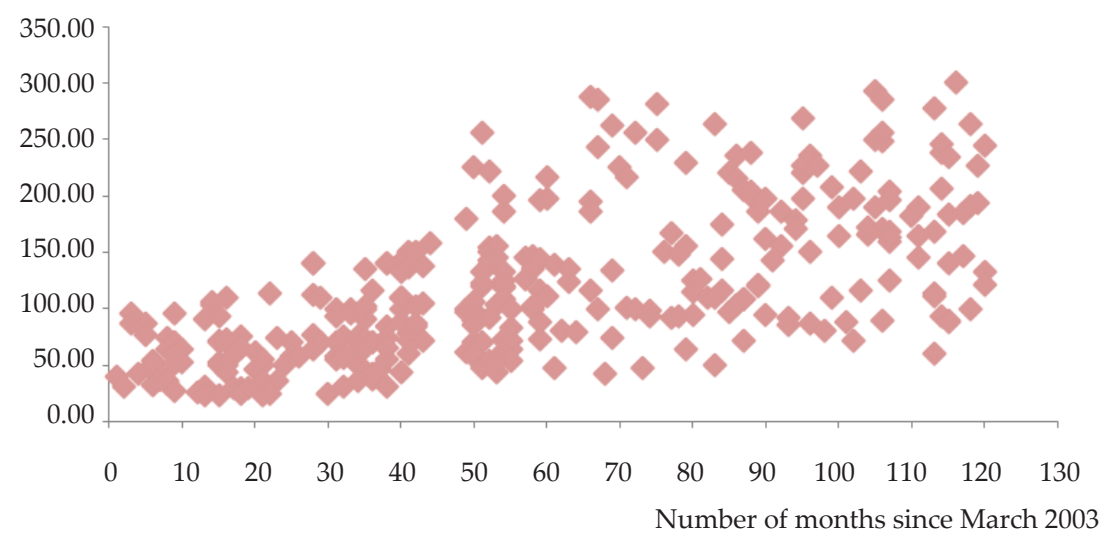

Fig. 3. Dispersion diagram of individual transaction prices in Wielka Wieś municipality in years 2003-2012 - residential development areas

In 2003, the average unit price of residential lands in the area of Wielka Wieś municipality was $57.11 \mathrm{PLN} / \mathrm{m}^{2}$, while in 2012 it amounted to $173.86 \mathrm{PLN} / \mathrm{m}^{2}$. On the basis of data collected the average unit prices achieved each year were calculated (Tab. 2) as well as minimum and maximum unit prices and the number of transactions.

Table 2. The basic parameters describing the level of prices achieved in the sale of undeveloped building lands in years 2003-2012

\begin{tabular}{|c|c|c|c|c|c|c|c|c|c|c||}
\hline \multirow{2}{*}{ Parameter } & \multicolumn{7}{|c|}{ Year } \\
\cline { 2 - 11 } & 2003 & 2004 & 2005 & 2006 & 2007 & 2008 & 2009 & 2010 & 2011 & 2012 \\
\hline \hline $\begin{array}{c}\text { Average } \\
\text { unit price } \\
{[\text { PLN/m²] }}\end{array}$ & 57.11 & 56.40 & 75.62 & 94.97 & 117.18 & 155.96 & 137.52 & 165.27 & 178.41 & 173.86 \\
\hline $\begin{array}{c}\text { Minimum } \\
\text { unit price } \\
{[\text { PLN/m²] }}\end{array}$ & 26.71 & 23.33 & 24.05 & 31.62 & 44.36 & 42.86 & 47.50 & 72.00 & 72.14 & 60.00 \\
\hline $\begin{array}{c}\text { Maximum } \\
\text { unit price } \\
{[\text { PLN/m²] }}\end{array}$ & 96.02 & 113.92 & 140.38 & 157.89 & 255.56 & 287.63 & 281.25 & 268.53 & 292.86 & 300.00 \\
\hline $\begin{array}{c}\text { Number of } \\
\text { transactions }\end{array}$ & 25 & 36 & 38 & 36 & 60 & 22 & 24 & 32 & 27 & 29 \\
\hline
\end{tabular}


Comparing the prices of agricultural lands to the lands of single-family housing function, achieved in 2012, a significant difference in their levels can be noticed. Unit prices for more attractive agricultural properties are about 9-10 PLN $/ \mathrm{m}^{2}$, and in case of construction areas they already reach the level $60-300 \mathrm{PLN} / \mathrm{m}^{2}$. The investment in this respect must take into account various risks that may affect the ability to achieve profits, but also the fees and expenses associated with the agricultural land conversion.

Possibility to convert the agricultural real property into a building one, as previously described, depends mainly on the spatial policy of municipality, which affects the use of land within its borders through the planning documents passed. This is the first and mandatory step that must be fulfilled in order to achieve the investment plans. Time plays an important role in this matter, in light of the number of years when the adoption of a new local plan or change of the existing one can take place. There is a fundamental risks associated with investing in agricultural lands, consisting in a possibility of a document being issued that will not authorize the use of a given property for construction purposes. What is more, it's up to the municipal authorities when the actions will be taken in relation to conversion of lands and these authorities bear the costs of analyses with regards to that. However, the law permits the change or preparation of local plans on the request of a party, but the municipalities also take into account the high costs associated to this.

It would be a difficult task to precisely define the catalogue of costs in relation to investing in farmlands because it is each time associated with a specific property located within a strictly specified market. However, the main expenses may include in particular:

- purchase price of agricultural property;

- agricultural tax, calculated in accordance with the Act on Agricultural Tax on the basis of the number of conversion hectares of the real property, determined depending on the land class, its use and tax district, in which the property is located; the location of the property in proximity to major urban areas does not affect the amount of tax; the contributing factors in this case are type and class of use; it should be noticed that the said agricultural tax also applies to building properties, which in the land register are designated as arable lands; thus, the mere fact of changing the function of the land cannot be the basis for property tax change; the change can only be implemented after conversion of lands from agricultural into residential ones [9];

- change of use fees, in line with the Farm and Woodland Conservation Act, which first of all involves the payments due, the amount of which depends on the class and type of land, soil origin and the tax district in which the land is located; additionally, the annual fees apply which constitute $10 \%$ of payment due, payable over a period of 10 years in case of permanent exclusion of the land from agricultural production; the fee is reduced by the value of the land, which in case of high real property prices with attractive location leads to 
payment remission and then only annual fees are charged; the level of payments possible to calculate fits in the range of 87,435 PLN/ha to 437,175 PLN/ ha, it should be noted that the costs mentioned are incurred after the construction project begins rather than at the time of land conversion, thus, in the case of sale of undeveloped land they are not the costs that encumber the person who is investing in agricultural land;

- real estate agency, investment advice and notary fees.

In case of the analysed Wielka Wieś municipality, the costs associated with investing in agricultural properties depend mainly on the purchase price of the land. Transactional market unit prices are at the level of about 3-10 PLN $/ \mathrm{m}^{2}$, with the average transactional unit price of approximately $6.5 \mathrm{PLN} / \mathrm{m}^{2}$.

The municipality was included in the second tax district, which is why the number of conversion hectares, on the basis of which the agricultural tax is calculated, equals minimum 0.15 and maximum 1.80 per one physical hectare.

In case of lands intended for single-family housing the unit prices range from $60 \mathrm{PLN} / \mathrm{m}^{2}$ to $300 \mathrm{PLN} / \mathrm{m}^{2}$, with the average price of $174 \mathrm{PLN} / \mathrm{m}^{2}$. Therefore, these prices are on average 25 times higher than the prices of agricultural properties, which guarantees profits at a very high level, certainly with the assumption that in a few years the conversion of agricultural lands into building ones will take place. In respect of lands with specific location assets there is no need to analyse the risk of decline in land value due to their limited supply. It should be emphasized that the number of sales transactions in relation to agricultural lands is very low in the analysed municipality, and recorded transaction prices are significantly lower than the offer prices, which are near the prices of building lands as of a few years ago, namely about $25-30 \mathrm{PLN} / \mathrm{m}^{2}$.

Considering the benefits of agricultural property investments, with regards to the increase in the prices of such properties, it is difficult to make prognoses for the analysed area on the basis of data collected. It results mainly from the fact that the number of transactions carried out in different locations in individual years was too low. The statistical data presented by the Central Statistical Office of Poland shows the increase in prices of agricultural properties in the Małopolska province of over $160 \%$ in the period 2004-2012. This value refers to lands more or less attractive in terms of location, therefore, with regards to the properties bordering with urban areas, effective rates will reach a much higher level.

\section{Conclusions}

Significant differences in the level of individual transaction prices obtained in agricultural property sales indicate the speculative nature of some of the contracts. For suburban markets, located in the vicinity of larger urban areas, the share of this type of transactions is much higher. Standard attributes, assumed for estimation 
processes, of agricultural lands, which determine the production capacity of those lands, cannot be treated as features explaining the variability of prices. Most of the agricultural lands in the described locations are not used for agricultural purposes, and their value is reflected by the investment opportunities, implemented as a result of transforming these lands into the areas of building function. The grounds for such actions are high prices of lands intended for development as well as the limited and decreasing land supply. Although the investment process entails a high risk of nonaccomplishment, the intentions of agricultural property buyers should be analysed while determining the market value of the properties.

\section{References}

[1] Bryx M., Matkowski R.: Inwestycje w nieruchomości [Real property investments]. Poltext, Warszawa 2001.

[2] Central Statistical Office of Poland, [on-line:] http://stat.gov.pl [access: 2014, january 31].

[3] Cymerman R.(red.): Planowanie przestrzenne dla rzeczoznawców majątkowych, zarzadców oraz pośredników w obrocie nieruchomościami [Spatial planning for real property appraisers, administrators and real estate agents]. Educaterra, Olsztyn 2006.

[4] Cymerman R. (red.): Podstawy rolnictwa i wycena nieruchomości rolnych [Introduction to agriculture and appraisal of agricultural properties]. Educaterra, Olsztyn 2011.

[5] Kucharska-Stasiak E.: Nieruchomość a rynek [Real property vs. market]. Wydawnictwo Naukowe PWN, Warszawa 2005.

[6] Powszechne Krajowe Zasady Wyceny [National General Appraisal Principles]. Polska Federacja Stowarzyszeń Rzeczoznawców Majątkowych, Warszawa 2012.

[7] Rogowski W.: Rachunek efektywności inwestycji [Cost-effectiveness calculation of investments]. Wolters Kluwer Polska, Kraków 2008.

[8] Schilbach J.: Charakterystyka nieruchomości rolnych oraz zasady ich wyceny [Agricultural properties' characteristics and the principles of their appraisal]. Akademia Rolnicza im. Hugona Kołłątaja w Krakowie, Szkoła Wiedzy o Terenie, Kraków 2001.

[9] Ustawa z dnia 21 sierpnia 1997 r. o gospodarce nieruchomościami. Dz. U. 1997, nr 115, poz. 741 [Real Property Management Act of 21 August 1997. Journal of Laws of 2010, No. 115, Item 741.

[10] Ustawa z dnia 3 lutego 1995 r. o ochronie gruntów rolnych i leśnych. Dz. U. 1995, nr 16, poz. 78 [Farm and Woodland Conservation Act of 3 February 1995. Journal of Laws of 2004, No. 16, Item 78].

[11] Wielka Wieś Municipality Office, [on-line:] http:/wielka-wies.pl [access: 2014, January 31]. 